\title{
"Metropolregionen" in Germany: The Enforcement of Global City-Regions
}

\begin{abstract}
Under the conditions of globalisation, economic success has been related in politics and theoretical debate to the strength of regions. The concept of the region has therefore also been strengthened in Germany. Within the architecture of a historically grown political landscape, the implementation of the new forms of so-called metropolitan governance, however, has had limited effects. While the limits of "new regionalism" in Germany - by the federal organisation of political geography - are evident, the very idea of regional governance is also to be challenged. Therefore, the article discusses whether the introduction of "Metropolitan regions" can be regarded in the light of the international research on global city-regions.
\end{abstract}

Keywords

Regions • Metropolitan governance $•$ Germany

(C) University of Warsaw - Faculty of Geography and Regional Studies
Frank Eckardt

Institute for European Urban Studies,

Bauhaus-Universität Weimar, Deutschland

e-mail: frank.eckardt@uni-weimar.de

Received: 29 May 2015

Accepted: 15 December 2015
Introduction

In the recent debate on equal living conditions in Germany, the focus has shifted towards the geographical level of the region (Jeffery et al. 2014). The actual controversy focusses on the relationship between new forms of regional governance ("metropolisation") and unequal development. The German case has thereby been linked to a larger discourse. For more than a decade, international scholars have argued that regions are replacing the city as the focal point of global flows in economy, culture and society. In this paper, the case of Germany will be presented to allow a continuation of the debate on whether a linkage to theories of "regionalization" can be further explored.

The theory of "new regionalism"

This argument mainly derives from two observations. First, cities have been transformed into regions by a new logic of spatial economy. This is the key finding of the so-called Los Angeles School, which asserts that the "urban" of today is following the post-Fordist development of "regional urbanization" (Soja 2014). This helps explain why large built areas have become the economic powerhouses of national geographies, bypassing the previously established national hierarchies of cities. Indeed, Los Angeles is the most evident example in the United States, leaving Chicago and the "rust belt" of the $19^{\text {th }}$ century industrial revolution behind. The second argument for a regional perspective on globalized geography takes note of the fact that former urban centres, particularly in Europe, have altered their role with regard to the connected hinterland. While the modern city was shaped with a clear distinction between the centre and the subordinated surroundings ("suburbs"), the new economic logic of high mobility and flexible production spaces enables a highly connected and networked landscape, where cities like London, Paris or Frankfurt can only function globally if they are intensively intertwined with their regional geography.

The assumption of a regionalized global economy is mainly based on functional evidence and mostly narrowed down to economic links between places within an agglomeration. It is apparent that the emergence of regional conglomerations gains the most attention in countries where concepts of interurban collaboration and sub-state organization have rather weak traditions, such as the United Kingdom and the United States. Here, the research often focuses on questions of how these regions can be steered and governed to be competitive on the world market. The analysis of how these new forms of regionalism fit together with pre-existing political geographies remains rather underdeveloped.

Often regarded as part of the "neoliberal agenda" (Harding 2007), the introduction of "new regionalism" is seen in this light as part of a broader political reframing in which austerity has become a crucial political objective. While it is widely assumed that Germany has benefitted from its early turn to austerity with "agenda 2010", the evaluation of the fiscal situation of German cities has to answer the question of whether the acclaimed benefit of a national agenda in favour of austerity has helped lessen the fiscal, economic and social differences between cities. This article will enlarge the scope on the ongoing local debt crises in these cities by exploring the altered role of cities in the overall political system. Following the view on the emergence of "new state spaces" (Brenner 2004), a broader look at local fiscal crises takes into account a more 
profound change in the relationship between state, society and economy, often coined as "post-Fordist". In contrast, however, to other international observations on regionalized geographies, the division between "sun belt" and "rust belt" areas is challenged with regard to German spatial organization.

\section{"New regionalism" in Germany}

The occurrence of dense economic activities in a highly internally and externally networked space seems to be the key spatial form of the globalizing economy (Amin \& Thrift 1992). After the establishment of the free global markets with their open exchange of goods and services, co-existing with a high degree of labour mobility and capital investments, a new centrality of spaces emerged around the globe. This process of centralization uses, but more often reshapes, existing urban structures to "regions" (Scott 2001). Hereby, the analytical perspective on the region as an agglomeration derives from the fact that functional and discursive elements of a "city region" are visible and coproducing. In other words, the existence of regionalism in Germany needs to be based on functional evidence and political governance or administration, so that the assumption of "new regionalism" would be justified.

The decentralized state architecture in Germany allows the "Länder" to define manners of regional collaboration in many ways. This has led to a wide range of initiatives to enable crossLänder regional associations (Walter-Rogg 2013), which have mostly become a more or less voluntary form of associating cities which are economically closely interlinked. In this way, politics reacted to the observed agglomeration effects and the need to build up globally competitive metropolitan areas (Eckardt 2006). When looking back on the history of regional planning in Germany, there are two ways of interpreting the federal system established after the Second World War. First, one can simply reject the significance of the region in the German context, as the most important level of decision making and steering takes place on the level of the Länder. Historically, some geographical areas of a "Land" have integrated functional regions in the sense of agglomerations. This is true for Berlin and Hamburg which mirror in scope the "greater Berlin" region of the 1920s. Beyond these "Stadtstaaten", there is no spatial equivalence between "Länder" and identifiable agglomerations. The most competitive agglomeration, Frankfurt Rhine-Main, crosses no less than five administrative territories of the Länder (cf. Zimmermann 2012). This is why a simple identification of the Länder as being a kind of "regional governance" is highly disputable. In some Länder agglomerations are part of their administrative space, as is the case for Rhine-Ruhr or Munich. Both examples also show that integration into a Land is challenging as well, as there are other agglomerative spaces included in these Länder.

In principal, therefore, it has to be said that the constitutional role of the "region" has little significance in the German case. The most important impact of the state constitution with regard to regional development comes from the national law on spatial planning (Bundesraumordnunsgesetz, ROG), which puts all spatial planning under the auspices of the Land, including the framework for regional governances. A stronger but rather indirect effect on the development of regions comes from the constitutional objective that citizens should have equal living conditions in all parts of the country. As a consequence, a complex system of rebalancing tax income, both among the Länder and among the cities within a Land, was established. Motivated by the same principle, the relocation of financial means to East Germany after the German Reunification has led to a system where not only federal resources but also decentralized Länder and cities contribute to the "Gemeinschaftsaufgabe Ost" (Common Effort East).
The need for an effective form of spatial planning that supports competitiveness, and the constitutional principle of German equality of living standards, were merged to argue for new forms of regional governance in the 1990s. The discussion on reforms of regional organization and cooperation to enable a better coordination of steering and thereby to enhance economic growth has led to a wide range of different governance models. One concept that has become crucial is the idea of the "metropolis" (Harrison \& Grow 2014: 29). With different economic profiles, political institutional frameworks and social embedding, the concept of the "metropolitan region" has not led to similar forms of governance (Heinelt \& Zimmermann 2011). The underlying assumption in the "Leitbild" (guiding idea) of the metropolitan region is that increasing voluntary association between local governmental bodies is in the interests of all participating cities as it will foster innovation, wealth and global competitiveness (cf. Hesse \& Leick 2013). The agglomerative context of each city is taken for granted as being a factor for economic growth because of effective regional governance.

It is evident, however, that the 11 metropolitan regions (See map 1) which were identified from a national point of view are only loosely following any kind of analytical concept or definition. Becoming a member of one of the metropolitan regions is rather a political statement, which demonstrates the will to be economically oriented and outward looking. A small city like Sonneberg in the South of the former East was therefore accepted as a member of the Nürnberg metropolitan region. Evidence for linkages with one metropolis or other can always be found, but the growing significance of the hinterland might question this assumed self-evidence (Growe 2013). The rather politically motivated attempt to enlarge the included network is the reason that, for example, the only East German metropolitan region in Saxonia included the city of Jena (in Thuringia) in its later development. Jena is regarded as one of the few boom towns in the East, but its wealth derives from a large university, research centre and high tech industries. Including this city into the Saxonian Triangle Metropolis (Dresden-Chemnitz-Leipzig) might enable more economic policy activities, and thereby in the long run increase economic growth in the region, but it also means that the metropolitan governance creates a spatial transformation rather than reacting to one.

The discursive character of the metropolitan region approach is therefore to be understood as ambivalent. In part, the metropolitan areas mirror existing functional agglomerative processes, with the hub and cluster geographies which are seen as typical in the international literature on the new city-regions. This is especially true for the Rhine-based organizations. Here, strong support - and, in the case of the Rhine-Neckar area, even the initiative for a metropolitan approach - comes from the global economic players. In part, the idea of a "metropolis" reflects a more political wish to display this kind of strong global space. While networking economic ties existed between Hannover, Braunschweig, Göttingen and Wolfsburg, it is hard to see that a city such as Wolfsburg, hosting the central Volkswagen factories in Germany, has much to do with the university city of Göttingen. These ties between cities which are separated by large areas of rural and peripheral areas exist; however, a metropolitan approach does not seem to offer new forms of regional governance. In conclusion, the new regionalism in Germany has led to a repositioning of spatial planning with regard to its role for economic competitiveness. This is in line with the Europeanisation of regional policies (Baudner \& Bull 2013) and with the redefinition of regional geographies by strong economic actors. However, in contrast to the examples prevalent in the literature on "new regionalism", the metropolitan approach in Germany not only reflects a kind of neo-liberal approach, but also goes hand-in- 


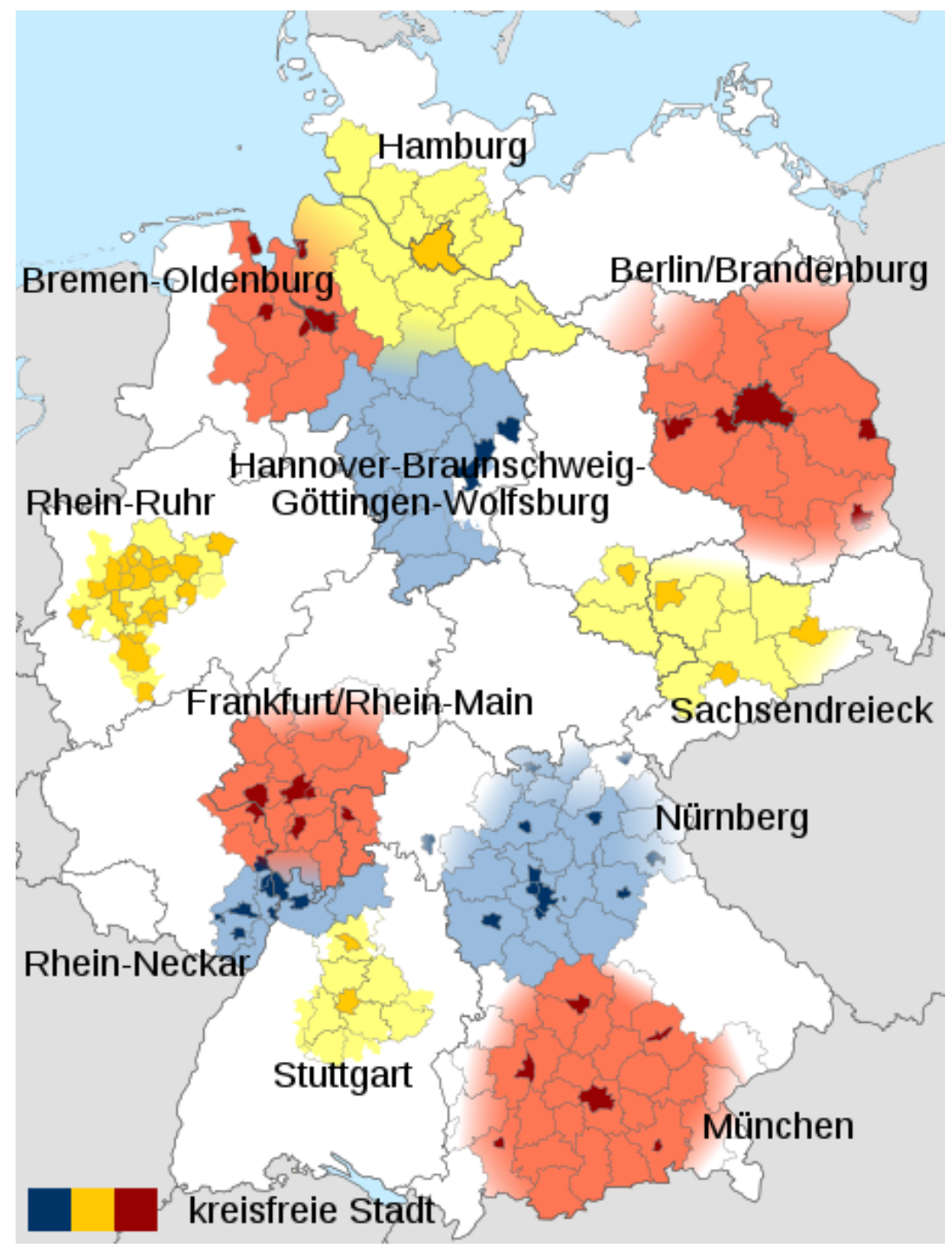

Map 1: The eleven metropolitan regions in Germany

hand with longer lasting forms of voluntary cooperation (cf. Terlouw 2013), the state architecture of financial balancing among regions (Länder) and cities, and the constitutional objective of equality. In this sense, regional governance by the metropolitan concept is not only an expression of a changed relationship between state, economy and space, where the "unbound" economy needs to be connected to the world markets, but also still an expression of a territorial embedding strategy. This has become even more obvious in other governmental programmes, where the state has been advancing as an entrepreneur (Gebhardt 2012).

\section{Discussion}

The concept of a metropolitan region relates to a variety of constitutional and political objectives, but emphasizes mainly the significance of an entrepreneurial understanding of regional and local governance. In this way, the introduction of metropolitan governance is the product of a broader political discourse, which has redefined the role of the state and the relationship between the different levels of the multi-layered federalism. The core of this approach lies in the idea of austerity. This implies that cities should be regarded as entities, which should be responsible for their position in regional and global markets. It therefore fosters the autonomies of cities to position themselves in the interurban competition for investments, inhabitants, social and cultural capital. A whole set of political implications are motivated by this overarching understanding of the "neoliberal" city (cf. Hackworth 2007).

While it is necessary to see the interference of policies as a consequence of a reoriented state philosophy - a paradigmatic shift towards economically and fiscally self-sustaining cities - it has to be taken into careful consideration that the intended changes have not been implemented in a pure form. The existing political and institutional landscape of a federal and corporative country like Germany hindered a mere adaptation to the imperatives of austerity. At the same time, harsher conditions for credit services reduced local autonomy. In contradiction to the prevalent austerity rhetoric, choice and space for alternative decisions in local politics has not increased. In this regard, German cities are placed into the same political framework and suffer from diminishing sovereignty - despite the economic and fiscal success of national policies - more than comparable international cases (Tonkiss 2013; Donald et al. 2014). The many negative effects of these policies, 
however, are still counterbalanced (albeit to an increasingly lesser extent) by a complex system of tax redistribution and the enlarged welfare state.

The metropolitan approach, which is relatively new for Germany and which has a different meaning than the "region" in many other countries, has been shown not to automatically contribute to the growth of the cities included. The examples discussed here indicate that the establishment of this kind of regional governance is highly motivated by the concepts known in regional studies as "new regionalism". A more careful look reveals the variety of spatial economies and longer lasting forms of interferences between the cities in each of these metropolitan areas. As is apparent, all included metropolitan regions are following paths deriving their political and societal construction from the industrial revolution. An unequal share of resources and power remains the intrinsic factor hindering a more intensive connectedness of cities in one metropolitan region. Being part of these forms of governance does not increase win-win situations but can even increase the loss of political autonomy of cities. This is the reason for cities like Hagen or Bremerhaven wanting to leave the metropolitan associations.

With regard to the theoretical discussions on state rescaling (Lord 2009), this article provides an insightful view on the case of Germany, which develops a rather irritating argument regarding the simple assumption of "rescaling". Contradictions between cities in German regions have become evident, and the existing federalism, along with the tradition of voluntary cooperation, point to the fact that regionalism and regional governance existed avant la lettre. How has this spatial organization prepared Germany to globalize its economy? A historical view might reveal that the idea of path dependency (Jessop 2002) could help to overcome the artificial search for "new" regionalism everywhere. The guiding concepts clearly derive from a US-UK comparison (Jonas \& Ward 2002), which should also include other economies prominent on the global markets.

\section{References}

Amin, A \& Thirft, N 1992, City: reimaging the urban, Polity Press, Cambridge.

Baudner, J \& Bull, MJ 2013, 'The Europeanisation of national institutions reassessed: A comparison of regional policies in Germany and Italy', Comparative European Politics, vol. 11, no. 2, pp. 201-221.

Brenner, N 2004, New state spaces - Urban governance and the rescaling statehood, Oxford University Press, Oxford.

Donald, B, Glasmeyer, A, Gray, M \& Lobao, L 2014, 'Austerity in the city: economic crisis and urban service decline', Cambridge Journal of Regions, Economy and Society, vol. 7, pp. 3-15.

Eckardt, F 2006, 'Innovation of Institutional Capacity in German Regions' in Synergy in Urban Networks, ed W Salet, Sdu Publishers, Den Haag, pp. 161-183.

Gebhardt. C 2012, 'The Entrepreneurial State; The German Entrepreneuerial Regions Programme', European Planning Studies, vol. 20, no. 9, pp. 1469-1482.

Growe,A2013, 'Regionalisierungsprozessevonwissensintensiven Dienstleistungsaktivitäten: Veränderung des Stadt-UmlandVerhältnisses im deutschen Städtesystem', Raumforschung und Raumordnung, vol. 71, no. 2, pp. 129-142.

Hackworth, JR 2007, The neoliberal city: governance, ideology, and development in American urbanism, Cornell Univ. Press, Ithaca.

Harding, A 2007, 'Taking city regions seriously? Response to on "city regions": new geographies of governance, democracy and social reproduction', International Journal of Urban and Regional Research, vol. 31, pp. 443-458.

Harrison, J \& Growe, A 2014, 'From places to flows? Planning for the new "regional world" in Germany', European Urban and Regional Studies, vol. 21, no. 1, pp. 21-41.

Heinelt, H \& Zimmermann, K 2011, 'How can we explain diversity in metropolitan governance within a country? Some reflections on recent developments in Germany', International journal of urban and regional research, vol. 35 , no. 6 , pp. 1175-1193

Hesse, M \& Leick, A2013, 'Wachstum, Innovation, Metropolregion. Zur Rekonstruktion des jüngeren Leitbildwandels in der deutschen Raumentwicklungspolitik', Raumforschung und Raumordnung, vol. 71, no. 4, pp. 343-359.
Jeffery, C, Pamphilis, NM, Rowe, C \& Turner, E 2014, 'Regional policy variation in Germany: the diversity of living conditions in a "unitary federal state"', Journal of European Public Policy, vol. 21, no. 9, pp. 1350-1366.

Jessop, B 2002, 'Time and space in globalization of capital and their implications for state power', Rethinking Marxism, vol. 14, no. 1, pp. 97-116.

Jones, M \& Ward, K 2002, 'A world of regionalism? Towards a US-UK urban and regional policy framework comparison', Journal of Urban Affairs, vol. 24, no. 4, pp. 377-401.

Knapp, W \& Schmitt, P 2008, 'Discourse on metropolitan driving forces and uneven development: Germany and the Rhine Ruhr Conurbation', Regional Studies, vol. 42, no. 8 , pp. 1187-1204.

Lord, A 2009, 'Mind the gap. The theory and practice of state rescaling: Institutional Morphology and the 'New' Cityregionalism', Space \& polity, vol. 13, no. 2, pp. 77-92.

Pijneburg, K \& Kholodilin, KA 2014, 'Do regions with entrepreneurial neighbours perform better? A spatial econometric approach for German Regions', Regional studies, vol. 48, no. 5, pp. 866-882.

Scott, A (ed) 2001, Global City-Regions: Trends, Theory, Policy, Oxford University Press, Oxford

Soja, EW 2014, My Los Angeles: from urban restructuring to regional urbanization, Univ. of California Press, Berkeley

Terlouw, K 2013,'Four centuries of translocal development in cities and regions in Northwest Germany', Globalizations, vol. 10 , no. 6 , pp. 871-886.

Tonkiss, F 2013, 'Austerity urbanism and the makeshift city', City,vol. 17, no. 3, pp. 312-324 .

Walter-Rogg, M 2013, 'Metropolitan governance over federal state borders in Germany: the example of the regions of Hamburg and Central Germany' in Governance and finance of metropolitan areas in federal system, ed E Slack, Oxford, Oxford Univ. Press, pp. 106-154.

Zimmermann, K 2012, 'Regionalreformen im Vergleich: München, Rhein-Neckar, Rhein-Main, Stuttgart und Hannover' in Die diskutierte Region: Probleme und Planungsansätze der Metropolregion Rhein-Main, ed J Monstadt, Campus, Frankfurt, pp. 315-334. 